\title{
Legal Politics on Tourism Village of Petang Sub- District in Badung-Bali District
}

\author{
I Wayan Wesna Astara ${ }^{1}$, I Made Suwitra ${ }^{2}$, I Made Mardika ${ }^{3}$ and Putu Ayu Sriasih Wesna ${ }^{4}$ \\ \{wesna_astara@yahoo.com ${ }^{1}$, madesuwitra@yahoo.co.id ${ }^{2}$, dikamar73@gmail.com ${ }^{3}$ and \\ sriasihwesna@gmail.com ${ }^{4}$ \} \\ Universitas Warmadewa, Denpasar-Bali, Indonesia
}

\begin{abstract}
Legal politics in explaining tourist villages in Plaga Village, especially the traditional village of Kiadan, is inseparable from the political and legal process to make the village of Plaga a tourism village. The issuance of the Decree of the Regent of Badung, number 47 of 2010 concerning the establishment of tourist village areas in Badung regency. One of the Plaga Villages in Petang District, which was set by the Badung Regency Government. The target of determining tourism villages is to increase the awareness of the community and local residents about the importance of environmental management and maintenance in an effort to maintain the existence of potential culture and existing tourism potential and at the same time to prosper the local community as tourism business owners. The aim of the research is to identify the potential of the village and the local wisdom that can be an attraction for tourist villages. The method used is qualitative which focuses on socio-legal in the development of legal research methods. The results of the legal political research on Plaga village have fostered the creativity of the local community to preserve local cultural values and natural potential as added values for their welfare. Nature tourism and cultural tourism are based on indigenous people by developing the potential of natural and local culture.
\end{abstract}

Keywords: Based on pakraman village; indonesian legal ideals; political law; tourism village

\section{Introduction.}

Politics of law ${ }^{4}$ Indigenous people in Bali in connection with tourism, in this regard refer to Law Number 10 of 2009 , concerning tourism. Tourism in Bali was born naturally which began when the Dutch colonial government came to power in Bali. Legal products related to Bali Culture tourism are Regional Regulation No. 2 of 2012, concerning Bali Cultural Tourism which can also regulate spiritual tourism in passing (Article 8, paragraph (m), and actually does not contain ecotourism in the text (article) Cultural Tourism in the view of cultural tourism in Bali must pay attention to local wisdom such as the beliefs of the Balinese people which are based on Tri Hita Karana and imbued by Hinduism (article 11, paragraph

\footnotetext{
${ }^{1}$ Dosen Fakultas Hukum Universitas Warmadewa.

2 Dosen Fakultas Hukum Universitas Warmadewa.

${ }^{3}$ Dosen Magister Administrasi Publik Pasca Sarjana Universitas Warmadewa.

${ }^{4}$ Sunaryati Hartono, 1991, Politik Hukum Menuju Sistem Hukum Nasional, Alumni, Bandung, hal. 1.
} 
(a)). When associated with cultural politics ${ }^{5}$ in Bali, that customary villages experienced state hegemony in legal political policy in defending the rights of traditional villages in Bali in the form of public policy (Customary Village Regulation Number: 06 of 1996) and subsequently revoked and replaced with Regional Regulation No. 3 of 2001 concerning Pakraman Village. Public policy in planning ${ }^{6}$ the importance of tourist villages in Badung has been planned by the Badung Regent Anak Agung Gde Agung period (2005-2010, and 2010-2015), Plaga Village was made as one of the villages chosen as the development area for Agro tourism in the North Badung region in accordance with the District II Development Badung through the Badung Regency Respondent Decree Number: 2028 of 19947. Furthermore, the Regent's Decree mentioned above was followed up with the issuance of Badung Regent Regulation Number 47 of 2010 concerning Determination of Tourism Village Areas in Badung Regency. But in fact the Implementation of this Regulation, is still experiencing obstacles in society caused by various aspects so that legal-sociological research is needed to be able to know the issues of culture, sociology, economics so that the community can be prospered in the presence of this regulation. Basically, this research is planned for 3 years of research from 2018 to 2020. In each year the focus of research and different problems is to be able to find out the potential, obstacles, from the local community in implementing the Regents Regulations. For this reason, the problems that arise in the first year of research (2018) are:

a. What is the cultural law politics of the local community whose village has been determined based on the public policy of Badung Regency?

b. What is the potential of the Village and local wisdom that can attract the tourist village?

\section{Result and Discussion}

2.1 Politics Legal culture of local communities Based on Badung Regent Regulations Number 47 of 2010 concerning Establishment of Tourism Villages in Badung Regency.

The journey of legal politics related to Cultural Tourism is a process of cultural political struggle with the politics of state law ${ }^{8}$, with the hope of Balinese culture as the basis for moving the "Spirit" of tourism in Bali. Tourism in its development and development uses Balinese regional culture inspired by Hinduism. In a cultural reality implied by an ideal there will be a reciprocal relationship between tourism and culture so that both of them increase in harmony ${ }^{9}$. Then the Regional Regulation No. 3 of 1991 concerning Cultural Tourism was revoked and replaced with Bali Province Regional Regulation Number 2 concerning Cultural Tourism, which also remained based on Balinese culture imbued with Hinduism and the Tri Hita Karana philosophy. the dynamic reciprocal relationship between tourism and culture that

\footnotetext{
5 Astara, I Wayan Wesna 2010, Pertarungan Politik Hukum Negara \& Politik Kebudayaan, Udayana University Press, Denpasar, h. 7.

${ }^{6}$ Astara, Wesna I Wayan, 2017, Public Policy and Role of Tradisional Security Offiser (Pacalang) of Religious Tolerance in the Tradisional Village Kuta-Bali, Journal of Law, Policy and Globalization, vol 67, 2017.

${ }^{7}$ I Ketut Sandhi Sudharsana, dkk, 2011, Pariwisata di Desa Plaga, "dalam jurnal Ilmiah Kertha Patrika”, h. 85 .

${ }^{8}$ Astara, I Wayan Wesna, Passim.

9 Peraturan Daerah Propinsi Bali Daerah Tingkat I Bali Nomor 3 Tahun 1991 tentang Pariwisata Budaya, Pasal 1, ayat (j).
} 
makes both develop synergistically, harmoniously and sustainably to provide prosperity to the community, cultural and environmental sustainability (article 1, paragraph (14).

In the context of authority, that the State of Indonesia as a pillar of the state of law, namely the principle of legality, then the governmental authority comes from legislation. Authority derived from legislation is obtained from three ways, namely, attribution, delegation, and mandate. According to H.D Van Wijk / William Konijnenbelt defines attribution, delegation and mandate as follows:

Attributie: toekening van een bestuursbevoegheid door een wetgever aan bestuursorgaan (Attribution is the administration of authority by legislators to government organs);

Delegatie: overdracht van een bevoegheid van het ene bestuurorgaan aan een ander, (delegation is the delegation of government authority from one organ of government to another government organ);

Mandaat: een bestuurorgan laat zijn bevoegheid namens hemuittoefenen door een ander (mandate is where the government allows its authority to be carried out by other organs in its name $)^{10}$.

In line with what was stated by Philipus M. Jadjon, that the source as a way of obtaining authority is that every act of government is required to be based on legitimate authority, and obtained from three sources, namely, attribution, delegation, and mandate ${ }^{11}$. This means that the DPRD, Governor, Regent have authority under the Law in carrying out their duties. Thus, the revocation of Regional Regulation No. 3 of 1991 concerning Cultural Tourism is not in accordance with the National Policy on tourism Law Number 10 of 2009 concerning Tourism. In Law No. 10 of 2009, one of the tourism businesses includes the provision of accommodation, water tourism, as well as no mention of tourism villages or eco-tourism, so as to fill the gap and balance the development of South Badung tourism with North Badung, the Badung Regent Anak Agung Gde Agung period (2005- 2010, and 2010-2015), Plaga Village was made as one of the villages chosen as the development area for Agro tourism in the North Badung region in accordance with the Badung Regency's Second Development Plan through the Decree of Badung Regency Number: 2028 of $1994^{12}$.

In order to realize the balance of development of South Badung with North Badung as well as equal distribution of people's welfare in the Badung Regent Period period (2005-2010, and 2010-2015), issued Badung Regent Regulation Number 47 of 2010 concerning Establishment of Tourism Village Areas in Badung regency. The tourism village in question is the area of preservation of the natural environment of the ecosystem and the traditional cultural nodes of the community by not hampering the development of its citizens ${ }^{13}$ to improve the welfare of his life through tourism efforts (Article 1, paragraph (6).

Village Potential and local wisdom that can be an attraction for tourist villages.

According to Jackson, 1989 (in Pitana, 205) there are 11 factors that become attractions attraction factors, namely: (1) location climate; 2) natonal promotion, 3) retail adververtising, 4) wholesale, 5) special events, 6) incentive schemes; 7) visiting friends; 8) visiting relations; 9) tourist attractions; 10) culture, and 11) natural environment and man-made environment. In

${ }^{10}$ Van Wijk/Willem Konijnenbelt, 2011, Hukum Administrasi Negara, Edisi Revisi, “dalam Ridwan HR, PT RadjaGrafindo, Jakarta, hal. 102.

${ }^{11}$ Philipus M Hadjon, 1998, Tentang Wewenang Pemerintah (Bestuurbevoegheid) "dalam Pro Justitia, Majalah Hukum Universitas Katolik Parahyangan, No. 1 Tahun XVI, Bandung, hal. 90.

${ }^{12}$ I Ketut Sandhi Sudharsana, dkk, Loc.cit.

${ }^{13}$ Catatan peneliti bahwa potensi Desa Kiadan digali, direvitalisasi, dikembangkan untuk kesejahtraan masyarakat local/desa adat dengan memperhatikan nilai kearifan local dan budaya local yang dapat menjadi nilai tambah untuk kesejahtraan masyarakat. 
relation to the factors that determine tourists to buy or visit attractions. Medlik, 1980 (in Ariyanto 2005), states that there are five factors that determine someone to buy services or visit a tourist attraction, namely: (1) location; (2) facility; (3) image; (4) cost, dan (5) service ${ }^{14}$.

Plaga Village has the potential to be developed into a tourist village as stipulated in the regulation of Badung Regent Number 47 of 2010 concerning Tourism Village Areas. Plaga Village has an area of 3,545 Km2 consisting of 9 Banjar Dinas, and 8 Adat Villages, 8 Banjar adat, 3 Subak Yeh and 8 Subak Abian. The 9 local community: namely 1) local community of Plaga; 2) local community of Kiadan; 3) local community of Nungnung; 4) local community of Tinggan; 5) local community of Bukian; 6) local community of Semanik; 7) local community of Tiyingan; 8) local community of Auman; 9) local community of Bukit Munduk; and then the names of traditional villages are: 1) Traditional Village of Plaga; 2) Traditional Village of Kiadan; 3) Traditional Village of Nungnung; 4) Traditional Village of Tinggan ; 5) Traditional Village of Bukian ; 6) Traditional Village of Semanik; 7) Traditional Village of Tiyingan; 8) Traditional Village of Auman ${ }^{15}$.

Kiadan Traditional Village as a tourism village of cultural pluralism can become cultural capital and cultural power which drives the life of the nation and state.16 Furthermore, it can be explained that the purpose of the law is to maintain order and social order in society as an instrument of social supervision. However, the legal ideals are to create legal justice, usefulness and certainty. Thus arrangements regarding tourist villages can be arranged in awig-awig desa adat or perarem, if it comes into contact with a third party, such as the provisions contained in the Regional Regulation of Bali Province No. in 1991 concerning Cultural Tourism and Regional Regulation No. 2 of 2012 concerning Bali Culture tourism is a form of recognition of the Regional Government towards Pakraman village as the subject of the agreement law in the management of tourist objects, such as cooperation agreements in the management of tourism objects in Bali carried out by the regional government with expertaman villages. The agreement can be made with a notary deed between the regional government and the traditional village / expert as the owner of a tourist object Karangasem Regency and underhanded agreement regarding the management and revenue sharing of Gianyar Regency. Regional cooperation agreement made with the Memorandum of Understanding model between the Regional government and Pakraman village, then followed up by the Regent's decision regarding the implementation of the Management of tourist objects and attractions, (in Badung Regency) ${ }^{17}$.

The concept of Tourism Village developed in the traditional village of Kiadan is natural tourism, cultural tourism, then "designed" with a pattern of accommodation that is suitable for rural communities. Community life with tourism activities can be integrated. Development of accommodation facilities in tourist village areas by being directed to the use of houses and

\footnotetext{
${ }^{14}$ I Gusti Bagus Rai Utama, 2012, Agro Wisata sebagai Pariwisata Alternatif di Indonesia Solusi Masif Pengentasan Kemiskinan, h. 21.

${ }^{15}$ Rencana Pembangunan Jangka Menengah Desa Semesta Berencana Desa Pelaga Kecamatan Petang Kabupaten Badung Tahun 2014-2020, h. 4-5.

16 Astara, I Wayan Wesna, 2017, Human Right and Conflict of Custom in Bali (The Case of "caste Status" Change Caused Kesepakang in Bungaya Traditional of Karangasem, Journal of law, Policy and Globalization, Vol. 60, 2007, Passim.

${ }^{17}$ I Wayan Arka,2016, Desa Adat sebagai Subyek Hukum Perjanjian, Udayana Unversty Press, h. 250251.
} 
unproductive vacant land as accommodation facilities and facilities to support village tourism ${ }^{18}$

Other potential that can be lifted is the attraction of tourists to the Traditional Village of Kiadan is a local tradition ${ }^{19}$ who live in the Kiadan community, there are 11 springs of water that can attract tourists, certain events to be used as attractions such as traditional ceremonies (piodalan, ngaben) can be developed as a religious tourism. Pancoran 11 this spring is sacred and diempon by 4 local community namely local community of Kiadan, local community of Bukian, local community of Nungnung, and local community of Sandakan (Sulangai Village). The concept of springs in the traditional village of Kiadan and the area of ownership / managed by four (4) local community mutually ${ }^{20}$.

In the management of tourist objects there has not been good coordination between the traditional village of Kiadan and the village of Plaga. Then there are still ambiguous management arrangements between managed by customary villages or by Subak as managers. For this reason, it is necessary to sit together between the owner of the accommodation with the customary village and the Dinas Village and tourism managers for legal certainty in the management of tourism villages in Kiadan in particular, and Tourism Village in North Badung in general for the occurrence of hormonal authority.

\section{Conclusion.}

The politics of Plaga Tourism Village is a manifestation of the implementation of several legal products regarding tourism Law Number 10 of 2009 concerning tourism, Bali Province Regional Regulation Number 2 of 2012 concerning Cultural Tourism, and Badung Regent Regulation Number 47 of 2010 concerning Determination of Tourism Villages in Badung Regency. Implementation of Regulations Regents of the Regent give hope to tourist villages to exercise their rights and obligations as land owners and / or residents who conduct environmental management / utilization activities in the tourist village areas of Plaga and Kiadan by making accommodations for the benefit of foreign and domestic tourists.

The potential tourist attraction of the village of Kiadan Plaga as a tourist village (coffee farm) and on the sidelines of coffee can be carried out by tourism attractions. In addition, religious tourism can be developed, there are temples that support as a religious village tour, shafts etc. Other potentials that have been grown are residential houses that can be used as accommodation. The local wisdom of Bali in a traditional village can be designed as houses for accommodation, and on the stage / attraction of jogged art in Bali can be staged directly in the place of tourists staying (lodging) because the natural atmosphere is very supportive.

\section{References}

[1]. Astara, I, W, W.: Human Right and Conflict of Custom in Bali, The Case of "caste Status" Change Caused Kesepakang in Bungaya Traditional of Karangasem, Journal of law, Policy and Globalization, Vol. 60 (2017)

\footnotetext{
${ }^{18}$ Implementasi Peraturan Bupati Badung Nomor 47 Tahun 2010 tentang Penetapan kawasan desa wisata di Kabupaten Badung, Pasal 7 ayat (3),

${ }^{19}$ I Wayan Wesna Astara, 2018, Custom, Hindu Religion, Local Law, and Social Change in Bali in the context of Tourism, "Dalam Prosiding Seminar International di Universitas Hindu Indonesia," Passim.

${ }^{20}$ Wawancara pada tanggal 11 Mei 2018, dengan Wayan Juana, Umur: 45 tahun, Jabatan Kepala Lingkungan Br Kiadan, Alamat: Br. Kiadan Plaga.
} 
[2]. Astara, I, W, W.: Public Policy and Role of Tradisional Security Offiser (Pacalang) of Religious Tolerance in the Tradisional Village Kuta-Bali, Journal of Law, Policy and Globalization, vol 67 (2017)

[3]. Astara, I, W, W.: Custom, Hindu Religion, Local Law, and Social Change in Bali in the context of Tourism, Dalam Prosiding Seminar International di Universitas Hindu Indonesia (2018)

[4]. Astara, I, W, W.: Pertarungan Politik Hukum Negara \& Politik Kebudayaan, Udayana University Press, Denpasar (2010)

[5]. Arka, I, W.: Desa Adat sebagai Subyek Hukum Perjanjian, Udayana Unversty Press (2016)

[6]. Utama, I, G, B, R.: Agro Wisata sebagai Pariwisata Alternatif di Indonesia Solusi Masif Pengentasan Kemiskinan (2012)

[7]. Hartono, S.: Politik Hukum Menuju Sistem Hukum Nasional, Alumni, Bandung (1991)

[8]. Sandhi, I, K and Sudharsana, dkk.: Pariwisata di Desa Plaga, "dalam jurnal Ilmiah Kertha Patrika (2011)

[9]. Rencana Pembangunan Jangka Menengah Desa Semesta Berencana Desa Pelaga Kecamatan Petang Kabupaten Badung Tahun 2014-2020.

[10].Philipus, M, H.: Tentang Wewenang Pemerintah (Bestuurbevoegheid) dalam Pro Justitia, Majalah Hukum Universitas Katolik Parahyangan, No. 1 Tahun XVI, Bandung (1998)

[11].Wijk, V and Konijnenbelt, W.: Hukum Administrasi Negara, Edisi Revisi, dalam Ridwan HR, PT Radja Grafindo, Jakarta (2011)

[12].Law of the Republic of Indonesia Number: 10 of 2009, concerning Tourism.

[13].Regional Regulation of Bali Province Level I Bali Number 3 of 1991 concerning Cultural Tourism.

[14].Regional Regulation of Bali Province Number 2 of 2012 concerning Cultural Tourism,

[15].Badung Regent Regulation Number 47 of 2010 concerning Determination of Tourism Villages in Badung Regency. 